\title{
PENGARUH PENAMBAHAN BUBUK UDANG REBON (Acetes Erythaeus) TERHADAP KANDUNGAN GIZI DAN DAYA TERIMA MENU PEMBERIAN MAKANAN TAMBAHAN (PMT) BALITA DI POSYANDU
}

\author{
Anis Abdul Muis, Uun Kunaepah, Alina Hizni, Priyo Sulistiyono \\ Poltekkes Kemenkes Tasikmalaya \\ Email:aamuiz@gmail.com
}

\begin{abstract}
The proportion of underweight children and stunting increased between 2007-2013. Underweight increased from $18.4 \%$ to $19.6 \%$ and stunting increased from $36.8 \%$ to $37.2 \%$ (Ministry of Health, 2013). Less food intake, the economic capacity of families and the lack of food cheap source of animal protein available and can be consumed by children under five is the cause of the problem. Small Shrimp (Aceteserythraeus) contains high protein and calcium, but not yet utilized optimally for nutritional improvement. This study aims to determine the acceptability of infants in food supplementary added Shrimp Powder (SP).This type of research is the experiment, with the design Randomised Control Trial (RCT) in the form of the acceptance test with the addition Shrimp Powder (SP) of menu food supplementary in infants at posyandu. Sampling RW.09 Village Kesunean Cirebon purposive sampling in the coastal areas with a high prevalence of malnutrition. A total sample of 60 toddlers of 30 toddlers and 30 toddlers control treatment, taken by systematic random sampling that meets screening criteria. Southwestern acceptance test results received of menu food supplementary with the addition Shrimp Powder $5 \%$ was slightly lower (79.9\%) of the reception menu food supplementary without SP (87.5\%) and showed no statistically significant differences $(p=0.215)$. Talam cake has received the highest power, then grits and steamed noodles. Shrimp powder at menu, 6,1-25,5kkal contributed to increasing energy, protein and calcium 1,3-5,5g 1,2-5,2mg per $100 \mathrm{~g}$ food supplementary. SP can not be added in large quantities $( \pm 5 \%)$, because it will affect the flavor and acceptability toddlers. To optimize SP contribution in improving the nutritional content of supplementary menu, then added in small portions $( \pm 5 \%)$, but often.
\end{abstract}

Keywords: children, shrimp powder, acceptance, food supplementary

\section{ABSTRAK}

Proporsi balita gizi kurangdan dan pendek (stunting )meningkat antara tahun 2007-2013. Balita gizi kurang meningkat dari 18,4\% menjadi 19,6\% dan balita pendek meningkat dari 36,8\% menjadi 37,2\%(Kemenkes 2013). Asupan makanan yang kurang, kemampuan ekonomi keluarga serta minimnya makanan sumber protein hewani murah yang tersedia dan dapat dikonsumsi oleh anak balita merupakan penyebab permasalahan tersebut. Udang rebon (Acetes erythraeus) memiliki kandungan protein dan kalsium yang tinggi, tapi belum dimanfaatkan dengan optimal untuk perbaikan gizi balita. Penelitian ini bertujuan untuk mengetahui daya terima balita pada PMT Bubuk Rebon. Jenis penelitian adalah experiment, dengan disain Radomized Control Trial (RCT) berupa uji penerimaan PMT posyandu dengan penambahan BUR pada balita. Pengambilan sampel RW.09 Kelurahan Kesunean Cirebon secara purposive sampling yaitu di daerah pesisir dengan prevalensi gizi kurang yang tinggi. Jumlah sampel sebanyak 60 balita yang terdiri dari 30 balita perlakuan dan 30 balita kontrol, diambil dengan sistematik random sampling yang memenuhi kriteria penapisan. Hasil uji penerimaan daya terima PMT BUR-5\% sedikit lebih rendah (79,9\%) dari penerimaan PMT non-BUR (87,5\%) dan secara statistik menunjukan tidak terdapat perbedaan secara signifikan $(p=0,215)$. Kue talam memiliki daya terima yang tertinggi, kemudian bubur jagung dan buras mi. Pemberian BUR pada PMT berkontribusi meningkatkan energi 6,1-25,5kkal, protein 1,3-5,5g dan kalsium 1,2-5,2mg per $100 \mathrm{~g}$ PMT. BUR tidak bisa ditambahkan dalam jumlah banyak ( $\pm 5 \%)$, karena akan mempengaruhi citarasa dan daya terima balita. Untuk mengoptimalkan kontribusi BUR dalam meningkatkan kandungan gizi menu PMT, maka pemeberiannya dalam porsi kecil ( $\pm 5 \%)$, tapi sering.

Kata kunci : balita, bubuk rebon, daya terima, PMT 


\section{PENDAHULUAN}

Permasalahan balita gizi kurang merupakan masalah kesehatan masyarakat yang serius, WHO menyebutkan batasan gizi kurang di satu wilayah tidak lebih dari $10 \%$ dan stunting tidak lebih dari $20 \%$ (Kemenkes 2010). Status gizi balita secara langsung dipengaruhi oleh asupan gizi dan penyakit infeksi (Supariasa et al., 2001). Balita dan anak prasekolah usia 4-5 tahun membutuhkan energi, protein dan kasium yang cukup untuk pertumbuhan, pemeliharaan dan metabolisme tubuh (Almatsier et al., 2011). Anak dengan asupan gizi kurang terutama protein dan kalsium akan mengakibatkan gangguan pertumbuhan, sehingga anak bergizi kurang dan berperawakan pendek. Asupan makanan yang kurang disebabkan beberapa faktor antara lain kemampuan ekonomi keluarga serta minimnya makanan sumber protein hewani murah yang tersedia dan dapat dikonsumsi oleh anak balita (Sediaoetama 2010).

Asupan gizi balita dapat diperoleh dari menu makanan keluarga dan PMT). Pemberian Makanan Tambahan (PMT) pemulihan ditujukan untuk memulihkan balita gizi kurang. PMT penyuluhan ditujukan untuk memberikan contoh bentuk menu bergizi dan sehat pada masyarakat pengunjung posyandu (Kemenkes.RI.,2010). Kualitas makanan tambahan yang belum memenuhi standar akan menambah buruk asupan balita, sehingga PMT posyandu yang diharapkan dapat memberikan tambahan asupan gizi pada balita di posyandu masih belum tercapai dengan optimal(Kemenkes.RI. 2010).

Udang rebon (Acetes erythraeus) sebagai pangan lokal daerah pesisir memiliki potensi kandungan nutrisi yang baik terutama kandungan protein dan kalsium yang tinggi (Astawan 2009). Protein udang rebon kering per $100 \mathrm{~g}$ mencapai $66,4 \mathrm{~g}$ atau setara dengan 2-3 kali protein daging sapi dan 3-4 kali protein telur, serta mengandung kalsium $41 \mathrm{mg}$ atau setara dengan 10 kali kalsium daging sapi (PERSAGI 2009). Udang rebon di daerah pesisir keberadaanya cukup melimpah dan murah, harga satu kilogram udang rebon di pasar tradisional berkisar Rp. 20.000,- atau 4 kali lebih murah dibanding harga daging yang mencapai $\mathrm{Rp}$. 90.000,- per kilogram. Udang rebon potensial menjadi pangan sumber protein hewani alternatif, yang murah dan dapat digunakan sebagai suplemen protein dan kalsium alami balita. Udang rebon dapat ditambahkan dalam makanan untuk meningkatan protein dan kalsium makanan, sebagai lauk maupun sebagai bahan makanan campuran (BMC) dengan tujuan 
melengkapi gizi dan meningkatkan mutu organoleptiknya (Kemenkes.RI. 2010).

Penelitian terkait pemanfaatan potensi udang rebon sebagai sumber protein hewani sudah dilakukan, seperti campuran bahan (mix) atau penambah bahan makanan dalam satu produk makanan baru atau sebagai salah satu komponen bahan makanan. Hasil penelitian tersebut telah membuktikan bahwa udang rebon dapat diterima (disukai) pada berbagai produk seperti sebagai bumbu penyedap (trasi), bola-bola tempe (Fatty 2012), kukis (Sipayung 2013), biskuit (Djundjung 2011), nugget (Desmelati et al,. 2013) dan mie instan (Haryati et al., 2006) berbahan udang rebon.

Udang rebon dapat dimanfaatkan lebih optimal dengan menjadikan bubuk udang rebon (BUR) sebagai bahan tambahan makanan atau suplemen makanan. Studi udang rebon sebagai formula siap saji yang dapat dikonsumsi balita dengan aman, mudah dan murah, serta praktis perlu dilakukan. Penelitian ini merupakan penelitian lanjutan dari penelitian formulasi bubuk udang rebon (BUR) yang mengasilkan formula penambahan bubuk rebon yang paling disukai adalah 5\% (Priyo Sulistiyono et al., 2015). Penelitian ini bertujuan untuk melihat konsistensi penerimaan PMT Posyandu yang ditambahkan bubuk udang rebon 5\%. Hasil penelitian diharapkan dapat digunakan sebagai bukti empiris tentang daya terima PMT balita yang ditambahkan bubuk udang rebon di posyandu.

\section{METODE}

Penelitian ini bersifat eksperimental dengan disain two group post test.Kelompok perlakuan diberikan menu PMT-BURdan pada balita kontrol diberikan PMT tanpa BUR di posyandu.

Bahan utama yang digunakan dalam penelitian ini adalah udang rebon (Acetes erythraeus). Udang rebon yang digunakan adalah rebon kering,varietas lokal cirebon yang diperoleh dari pasar tradisional Kanoman Kota Cirebon. Varietas ini dipilih karena banyak tersedia di pasaran sebagai hasil tangkapan nelayan di wilayah Cirebon. Jenis dan bahan pembuatan PMTposyandu adalah bahan yang biasa digunakan ibu kader posyandu yang mudah didapat dipasaran.

Peralatan pembuat bubuk udang rebon (oven, blender, ayakan kain, pengaduk adonan, timbangan makanan.Alat pembuat PMT berupa peralatan dapur yang biasa digunakan kader, meliputi panci, dandang, cetakan, sendok pengaduk dan oven. Analisis nilai gizi menu posyandu menggunakan software nutrisurey dan pengujian daya terima pada balita di 
posyandu menggunakan skala comstock. Pengujian daya terima PMT BUR dilakukan pada balita (2-5 tahun) sebanyak 60 balita, yang terdiri dari kelompok perlakuan 30 balita dan kelompok kontrol sebanyak 30 balita di Posyandu RW.09 Kesunean Selatan Kelurahan Kesepuhan Kecamatan Lemah Wungkuk Kota Cirebon, dengan kriteria inklusi balita telah diberikan makanan seperti orang dewasa, tidak memiliki riwayat alergi pada udang/rebon dan sejenisnya, tidak sedang sakit, tidak habis makan 2 jam yang lalu dan ersedia menjadi subjek penelitian atas persetujuan orang tua.

\section{HASIL DAN PEMBAHASAN}

\section{Daya terima PMT BUR}

Penelitian ini merupakan tahap ke-

2 dari tahap sebelumnya yaitu melihat kandungan gizi BUR dan uji organoleptik oleh panelis. Uji daya terima dimaksudkan untuk mendapatkan bukti-bukti konsitensi dari penerimaan anak balita pada PMT BUR.

$$
\begin{aligned}
& \text { Jumlah anak yang diundang } \\
& \text { sebanyak } 60 \text { anak, namun dalam } \\
& \text { pelaksanaannya tidak semua anak hadir } \\
& \text { mengikuti penelitian. Jumlah anak yang } \\
& \text { hadir berbeda-beda dalam kurun } 3 \text { (tiga) } \\
& \text { kali uji daya terima (tabel 1). Penugasan } \\
& \text { pada anak untuk dijadikan perlakuan atau }
\end{aligned}
$$

kontrol dilakukan secara acak sitematis (Radomised Control Trial).

Tabel 1.

Waktu Pemberian, Jenis PMT dan

Jumlah Anak yang hadir mengikuti

Penelitian di RW.09 Kesunean Selatan Tahun 2016

\begin{tabular}{cccc}
\hline $\begin{array}{c}\text { Tanggal Pemberian } \\
\text { PMT }\end{array}$ & $\begin{array}{c}\text { Jenis } \\
\text { PMT }\end{array}$ & $\begin{array}{c}\text { Jumlah } \\
\text { Anak }\end{array}$ & $\begin{array}{c}\% \\
\text { partisipasi }\end{array}$ \\
\hline 25 Oktober 2016 & Buras Mi & 52 & 86,7 \\
Kue & 55 & 91,7 \\
Talam & Bubur & & 95,0 \\
1 Nopember 2016 2016 & $\begin{array}{c}\text { Jagung } \\
\text { Kagung }\end{array}$ & 57 &
\end{tabular}

Pemilihan menu posyandu yang

dijadikan uji coba, dipilih atas pertimbangan kesukaan pada menu, kemudahan mendapatkan bahan dan pengolahannya serta karakteristik taste dari menu yaitu gurih dan manis. Dari 10 menu posyandu dipilih dua menu dengan karakteristi gurih dan satu menu dengan karakteristik manis. Hal tersebut karena BUR memiliki karakteristik gurih.

Rerata tingkat partisipasi responden sebesar $91,1 \%$ dan cenderung semakin meningkat dalam tiga kali pemberian. Dokter puskesmas diminta selalu pendamping saat pelaksanaan uji penerimaan untuk mengantisipasi adanya dampak kesehatan yang tidak diinginkan setelah mengkonsumsi PMT-BUR, seperti alergi atau diare. Sampai akhir penelitian tidak ada laporan keluhan kesehatan dari anak yang menjadi responden. 
Tabel 2.

Jumlah Anak mendapat PMT

Perlakuan dan Kontrol di RW.09

Kesunean Selatan Tahun 2016

\begin{tabular}{|c|c|c|c|c|c|c|}
\hline \multirow[t]{2}{*}{ Jenis PMT } & \multicolumn{2}{|c|}{$\begin{array}{l}\text { Perlakuan } \\
\text { (BUR) }\end{array}$} & \multicolumn{2}{|c|}{$\begin{array}{c}\text { Kontrol } \\
\text { (Non } \\
\text { BUR) }\end{array}$} & \multicolumn{2}{|c|}{$\begin{array}{c}\text { Jumlah } \\
\text { Anak }\end{array}$} \\
\hline & $\mathrm{n}$ & $\%$ & $\mathrm{n}$ & $\%$ & $\mathrm{n}$ & $\%$ \\
\hline Buras Mi & 26 & 50.0 & 26 & 50.0 & 52 & 100 \\
\hline $\begin{array}{l}\text { Kue } \\
\text { Talam }\end{array}$ & 25 & 45,5 & 30 & 54,5 & 55 & 100 \\
\hline $\begin{array}{l}\text { Bubur } \\
\text { Jagung }\end{array}$ & 28 & 49.1 & 29 & 50,9 & 57 & 100 \\
\hline
\end{tabular}

Pemberian penugasan sebagai perlakuan atau kontrol dilakukan secara redom pada awal pemberian.Pemberian kedua dan ketiga dilakukan sistem silang (cross).

Hasil uji penerimaan PMT pada anak dilakukan dengan mengkur sisa makanan yang diberikan dalam 1 porsi. Satu porsi pemberian buras mi dan kue talam sebesar $\pm 50 \mathrm{~g}$ (satu potong) dan Bubur Jagung sebanyak $\pm 110 \mathrm{~g}$ (setengah mangkok).

Alat ukur sisa makanan menggunakan skala visual comstock yaitu melihat secara langsung (visual) sisa porsi makanan yang diberikan pada anak. Hasilnya dikategorikan menjadi lima kreteria yaitu $0 \%$ (habis), 25\% (sisa $1 / 4$ porsi), $50 \%$ (sisa $1 / 2$ porsi), $75 \%$ (sisa $3 / 4$ porsi) dan $100 \%$ (tidak dimakan/hanya sedikit yg dimakan).

Hasil pengukuran penerimaan PMT BUR rerata mencapai 79,9\% dan non-
BUR 87,9\%. PMT BUR memiliki penerimaan yang lebih rendah, namun hasil uji beda Mann Whitney menunjukan tidak terdapat perbedaan yang signifikan $(p=0,225)$ antara penerimaan anak terhadap PMT BUR dan non-BUR. Hal tersebut menunjukan penerimaan PMT BUR sama dengan PMT non-BUR.

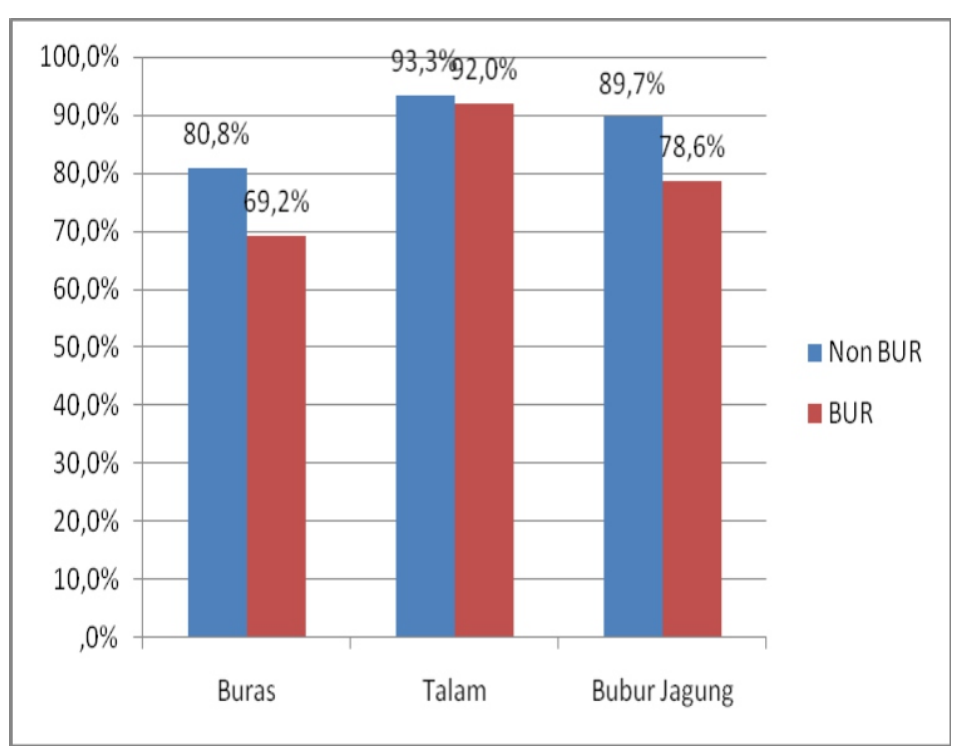

\section{Gambar 6. Daya Terima PMT BUR dan non-BUR}

Daya terima PMT posyandu dengan formulasi bubuk udang rebon terpilih (BUR-10\%) pada Buras Mi menunjukkan bahwa PMT dengan penambahan BUR-10\% dapat diterima oleh $69,2 \%$ anak balita. Hal tersebut diukur dari satu porsi buras mi yang diberikan sekitar $60 \mathrm{~g}$ per balita. Penabahan BUR-5\% pada KueTalam (92\%) dan Bubur Jagung $(78,6 \%)$ menunjukan peresetase penerimaan yang lebih tinggi. Hasil penelitian Sulistiyono (2015) pada uji 
penerimaan bolu kukus dengan BUR-5\% menunjukkan angka yang lebih baik yaitu mencapai 88\% dan Bubur lemu mencapai $80 \%$.

Hasil penelitian lain menunjukan angka penerimaan pada produk produk ikan dan udang rebon seperti bola-bola tempe (Fatty, 2012), kukis (Sipayung, 2013), biskuit (Djundjung, 2011) dan mie instan (Haryati et al., 2006) dengan penerimaan berkisar antara 50-80\%,. Hasil uji penerimaan nugget udang rebon, menunjukan angka yang lebih tinggi mencapai 90\% (Desmelati et al., 2013). Hal tersebut karena karateristik naget yang gurih (umami) sesuai dengan citarasa udang rebon.

Jika dibandingkan dengan beberapa penelitian lain yang menggunakan bahan pangan sejenis (udang dan rebon) maka rerata penerimaan (suka) pada PMT BUR pada penelitian sudah cuku baik yaitu mencapai 79,9\%. Penelitian ini perlu dicobakan lebih banyak lagi agar data bukti empiris konsistensi penerimaan PMT BUR lebih akurat lagi. Hal ini menurut winarno (1987) dapat dijadikan makanan tambahan pada balita karena penolakan (rasa yang tidak disukai) tidak melebihi $25 \%$.

\section{Nilai gizi PMT BUR}

Analisis nilai gizi PMT BUR dan non-BUR dilakukan dengan menggunakan teknik komposit bahan penyusun menu PMT termasuk berat bahan dalam satuan berat (gram) dengan penimbangan, selanjutnya dianalisis nilai gizi menggunakan Software Nutrisurvey.

Hasil analisis tiga menu yang diujikan; Buras Mi, Kue Talam dan Bubur Jangung adalah sebagai berikut :

Tabel 7.

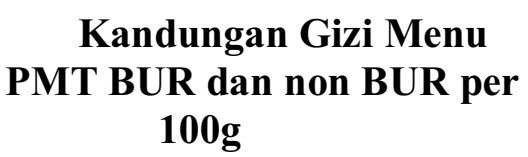

\begin{tabular}{|c|c|c|c|c|}
\hline $\begin{array}{l}\text { Jenis } \\
\text { PMT }\end{array}$ & Perlakuan & $\begin{array}{c}\text { Ener } \\
\text { gi } \\
(\mathrm{kkal} \\
)\end{array}$ & $\begin{array}{l}\text { Protein } \\
\text { (g) }\end{array}$ & $\begin{array}{c}\text { Kalsium } \\
(\mathrm{mg})\end{array}$ \\
\hline & BUR & $\begin{array}{c}174 \\
0\end{array}$ & 11,4 & 24,7 \\
\hline $\begin{array}{l}\text { Buras } \\
\text { Mie }\end{array}$ & Non-BUR & $\begin{array}{c}148 \\
5\end{array}$ & 5,9 & 19,4 \\
\hline & BUR & $\begin{array}{c}455 \\
5\end{array}$ & 6,0 & 58,8 \\
\hline Talam & Non-BUR & $\begin{array}{c}445 \\
9\end{array}$ & 3,9 & 56,8 \\
\hline $\begin{array}{l}\text { Bubur } \\
\text { Jagung }\end{array}$ & Non-BUR & $\begin{array}{c}120 \\
7\end{array}$ & 7,5 & 6,7 \\
\hline
\end{tabular}

Penambahan BUR 10\% pada Buras Mi dan penambahan BUR 5\% pada menu Kue Talam dan Bubur Jagung. Hasil analisis nilai gizi menunjukan penambahan BUR pada PMT berkontribusi menambah energi 6,1-25,5 kkal, protein 1,3-5,5g dan kalsium 1,2-5,2 mg per 100g PMT. 
Hasil analisis nilai gizi menunjukan penambahan BUR pada PMT menambah energi 6,1-25,5 kkal per 100g PMT. Kandungan energi yang dapat dikonsumsi balita tergantung dari besar porsi yang dapat dikonsumsi balita dan persentase BUR yang ditambahkan. Jika jumlah yang dikonsumsi $100 \mathrm{~g}$, setara dengan 455,5kkal energi, atau PMT BUR dapat berkontribusi 28,5\%AKG energi yang dianjurkan untuk balita 4 - 6 tahun sebesar 1600 kkal per anak per hari(Kemenkes.RI. 2013). Jika mengacu pada ketentuan bahwa PMT minimal dapat memberikan sumbangan seperempat dari kebutuhan energi sehari anak (400 kkal)(Kemenkes.RI. 2010), maka sesunggunya energi PMT BUR-5\% berupa kue talam sudah mencapai $>100 \%$ AKG yang berarti cukup baik karena melebihi dari $80 \% \mathrm{AKG}$ (Supariasa et al. 2001).

Protein adalah zat gizi yang sangat penting untuk tubuh, karena disamping sebagai bahan bakar juga berfungsi sebagai zat pembangun sekaligus pengatur. Protein adalah sumber asam amino yang mengandung unsur-unsur $\mathrm{C}$, $\mathrm{H}$, O dan $\mathrm{N}$ yang tidak dimiliki lemak atau karbohidrat. Sebagai zat pembangun, protein merupakan bahan pembentuk jaringan-jaringan baru yang selalu terjadi dalam tubuh. Pada masa pertumbuhan seperti masa balita proses pembentukan jaringan terjadi secara besar-besaran sehingga pada masa tersebut asupan protein harus cukup agar pertumbuhan balita tidak terganggu (Sediaoetama, 2010).

Hasil analisis nilai gizi menunjukan penambahan BUR pada PMT menambah protein $1,3-5,5 \mathrm{~g}$ per $100 \mathrm{~g}$ PMT. Kadungan protein tertinggi PMT BUR mencapai 5,5g yaitu pada PMT BUR-15\% Buras Mi atau mencapai $>50 \%$ standar minimal protein PMT sebesar 8 g(Kemenkes.RI. 2010).

Perbandingan protein PMT BUR5\% dengan Angka Kecukupan Gizi (AKG) protein yang dianjurkan untuk balita 4 - 6 tahun sebesar $35 \mathrm{~g}$ per anak per hari maka PMT BUR-5\% buras mi mencapai 18,9\% AKG. Seperti halnya energi, mengacu pada ketentuan bahwa PMT minimal dapat memberikan sumbangan seperempat dari kebutuhan protein sehari anak $(8,75 \mathrm{~g})$, maka protein PMT BUR-5\% baru mencapai 76,6\% AKG yang artinya bahwa PMT BUR 5\% belum mencukupi kebutuhan protein AKG(Indonesia's Ministry of Health Indonesia. 2013). Kebutuhan protein akan tercukup bila yang digunaakan minimal PMT BUR-10\% meskipun dengan daya terima yang lebih rendah. 
Hasil analisis nilai gizi menunjukan penambahan BUR pada PMT menambah kalsium 1,2-5,2mg per $100 \mathrm{~g}$ PMT. Kadungan kalsium tertinggi PMT BUR mencapai 58mg yaitu pada PMT BUR-15\% $\mathrm{ku}$ atau me talam atau mencapai $26 \%$ standar minimal kalsium PMT sebesar 250mg (Kemenkes.RI. 2010).

Perbandingan kalsium PMT BUR-5\% dengan Angka Kecukupan Gizi (AKG) kalsium yang dianjurkan untuk balita 4 - 6 tahun sebesar 1000 mg per anak per hari, maka PMT BUR-5\% kue talam mencapai $25,9 \% \quad \mathrm{AKG}$ (Indonesia's Ministry of Health Indonesia. 2013). Seperti halnya energi dan protein bahwa PMT minimal dapat memberikan sumbangan seperempat dari kebutuhan kalsium sehari anak (250 g), maka kalsium PMT BUR-5\% tertinggi baru mencapai $25 \%$ AKG yang berarti kurang karena dibawah AKG(Supariasa et al. 2001). Untuk dapat mengoptimalkan kontribusi protein dan kasium BUR maka pemberian BUR akan cukup jika diberikan porsi kecil tapi sering.

Hal tersebut baik mengingat fungsi kalsium penting pada masa pertumbuhan. Kalsium berperan membantu dalam pembentukan tulang dan gigi serta mengatur proses biologis dalam tubuh, sehingga kebutuhan terbesar kalsium adalah pada masa pertumbuhan seperti balita dan anak sekolah. Kalsium yang berada dalam sirkulasi darah dan jaringan tubuh berperan sebagai transmisi impuls syaraf, kontraksi otot, penggumpalan darah, pengaturan permiabelitas membran sel, serta keaktifan enzim (Sediaoetama, 2010)'

Untuk mengetahui pengaruh pemberian PMT BUR pada perbaikan gizi balita, maka perlu dilakukan studi pemberian dalam kurun waktu yang cukup.

\section{SIMPULAN}

Daya terima PMT BUR-5\% sedikit lebih rendah $(79,9 \%)$ dari penerimaan PMT non-BUR (87\%) dan secara statistik menunjukan tidak terdapat perbedaan secara signifikan $(p=0,215)$. Kue talam memiliki daya terima yang tertinggi, kemudian bubur jagung dan buras mi. Pemberian BUR pada PMT berkontribusi meningkatkan energi 6,1-25,5kkal, protein 1,3-5,5g dan kalsium 1,2-5,2mg per $100 \mathrm{~g}$ PMT. BUR tidak bisa ditambahkan dalam jumlah banyak $( \pm 5 \%)$, karena akan mempengaruhi citarasa dan daya terima balita. Jika porsi PMT yang diberikan sedikit, maka penambahan BUR hanya sedikit kontribusinya pada peningkatan gizi PMT. Untuk itu PMT BUR dapat 
dimanfaatkan dalam porsi kecil tapi sering, misalnya dibuat sebagai bumbu tabur.

\section{DAFTAR RUJUKAN}

Almatsier, S., Soetardjo, S. \& Soekatri, M., 2011. Gizi seimbang dalam daur kehidupan. Jakarta: Gramedia pustaka utama, pp.92,103-105.

Astawan, 2009. Udang rebon bikin tulang padat. , 2014(02 April 2014). Available at: http://cybermed.cbn.net.id/.

Desmelati, Sumarto \& Meilin, S., 2013. Consumer acceptance and quality assessment nugget shrimp (Acetes erythraeus). Journal of Agricultural Research, 8.

Djundjung, E., 2011. Utilization shrimps powder as a source of calcium and phosphorus in the manufacture of biscuit. Jakarta: Pelita Harapan University.

Fatty, A.R., 2012. The effect of adding shrimp against biological nutrient and hedonic test results on the ball-balls tempe. Jakarta: University of Indonesia.

Haryati, S., Sya'rani, L. \& Agustini, T.W., 2006. Study flour substitution mackerel, shrimp, crabs in various concentrations on the quality of physico-chemical and organoleptic instant noodles. Journal of Pasir Laut, 2.

Indonesia's Ministry of Health Indonesia., 2013. Regulation No. 75 -2013, Nutritional Adequacy recommended (RDA) for the nation of Indonesian,
Jakarta.

Kemenkes, 2013. Pokok-pokok hasil riset kesehatan dasar, Jakarta: Kementrian Kesehatan RI.

Kemenkes, 2010. Surveilans gizi di tingkat kabupaten/kota, Jakarta: Direktorat Bina Gizi Masyarakat Kementerian Kesehatan RI.

Kemenkes.RI., 2013. Angka Kecukupan Gizi yang Dianjurkan Bagi Bangsa Indonesia,

Kemenkes.RI., 2010. Pedoman pemberian makanan tambahan pada balita, Jakarta: Direktorat Bina Gizi Masyarakat Kementerian Kesehatan RI.

PERSAGI, 2009. Tabel Komposisi Pangan Indonesia, PT. Elex Media Komputindo, Kompas Gramedia.

Priyo Sulistiyono, Herawati, D.M.D. \& Arya, I.F.D., 2015. Formulasi Bubuk Udang Rebon pada Menu Pemberian Makanan Tambahan (PMT) Balita 4-5 Tahun di Posyandu Anggrek Kecamatan Harjamukti Kota Cirebon. Universitas Padjadjaran.

Sediaoetama, A.D., 2010. Ilmu Gizi I, Jakarta: Dian Rakyat.

Sipayung, E.N., 2013. Flour potential purple sweet potato (Ipomoea Batatas L. ), soybean flour and flour shrimp in making of cookies. Riau: Universitas Riau-Pekanbaru.

Supariasa, I.D.N., Bakri, B. \& Fajar, I., 2001. Penilaian Status Gizi, Jakarta: EGC. 
